\title{
Bringing the "social" back in: studies of production cultures and social theory
}

Vicki Mayer

\section{Abstract}

In this article, I argue that studies of media production should use grounded case studies in order to evaluate and reformulate classic social theories of production in light of the new spirit of capitalism. To wit, I present fieldwork with reality television casting personnel in which casters fail to achieve their industrial production goals. In this case, instances of failure may illustrate how the social concept of alienation is lived through processes of television production.

\section{Keywords}

Alienation. Failure. Production studies. Reality television. Social theory.

\section{Vicki Mayer I vmayer@tulane.edu}

Tulane University. Doutora em comunicação pela University of California, San Diego. Diretora do Departamento de Comunicação na Tulane University.

Este artigo é uma versão modificada e atualizada do capítulo 1 de MAYER, Vicki, BANKS, Miranda, and CALDWELL, John T. (EDS.) Production studies: Cultural studies of media industries. New York: Routledge, 2009.

\section{Introduction}

As a field of study, "production studies" captures for me the ways that power operates locally through media production to reproduce social hierarchies and inequalities at the level of daily interactions. Production studies, in other words, "ground" social theories by showing us how specific production sites, actors, or activities tell us larger lessons about workers, their practices, and the role of their labors in relation to politics, economics, and culture. It is this connection, between the micro contexts and the macro forces, which illuminate the social implications in an otherwise narrow case study and modify the grand claims, that have become commonplace regarding the role of media in society. Terms such as "hegemony," "ideology," and, in the case of the study below, "alienation" may describe general ways that media exert effects over subjects, but they cannot describe the particular ways that these forces are distributed to social groups differentiated by gendered, racial, and class positions. It is also this connection between macro and micro that is so frequently lost in the 
efforts to describe the current media landscape, its interconnected industries, and its networks of professionals. It is ironic that as media industries continue to aggregate and dominate larger labor markets and audience shares, fewer production studies have actually addressed the real ways that local communities construct their subjectivities in the face of these consolidations of media capital and reconfigurations of media work.

Social theory was not always divorced from local realities. From the 1930 s to the early 1950 s, a series of international scholars, many of whom published in the United States, tried to envision how media workers experienced the growth of a cinematic industrial complex based in Hollywood, and its attempts to harness and control labor power. Written at a time when many Americans were already deeply skeptical about the growing commercialization of culture and the threats of propaganda, both political and economic, these early foci on producers and production belie the desire for a holistic sense of how production and consumption intertwined in the lives of real people. They documented how alienation, a Marxist concept found in his Economic and Philosophical Manuscripts of 1844, operated to estrange people from the value of the things they made (MARX, 2000). For Marx, the bigger and more economically powerful a product was after its production, the more the workers who made it suffered. In the process, their work was devalued, erased by the value of a product they had no control over distributing. More importantly,
Marx highlighted the fact that modern capitalist societies require workers who recognize that their physical means of subsistence depend on this political economic system of creating wealth for others. This second characteristic of alienated labor is what made Hollywood workers such an apropos case study. Movies were arguably the most powerful goods the United States produced through a vast economy of laborers whose existence depended upon this product, which surpassed the value of the labor and devalued the work of the laborer. Looking back on early media production studies, we can see the ways that Leo Rosten (1941) and Hortense Powdermaker (1950) in particular theorized the concept of alienation through their empirical studies of Hollywood labor, work practices, and subjective experience.

Although shifts in the global political economy from production-based to consumer-based has rendered some of Marx's insights obsolete, it is his attempt to relate political economy to the formation of subjectivities that seems still useful to ponder today. In this article, I argue that we can still theorize alienation, but that it must come through empirical cases that contribute a broader understanding of work experience in light of what Luc Boltanski and Eve Chiapello call the "new spirit of capitalism," the zeitgeist that encompasses the present realities of capitalist production (BOLTANSKI; CHIAPELLO, 2005). To illustrate, I draw upon a single event in a longer ethnography of reality television casters as a new worker category in the television industry. The 
event - a casting call that failed to attract any participants - reveals some of the central ways in which local production studies might theorize forms of alienation in a grounded way, and why television industry workers labor to erase all trace of these theoretically productive moments.

\section{Social theory in two early production studies}

Leo Rosten's study of 1930s Hollywood begins with a simple restatement of division between superstructure and base, or the difference between the lavish appearances in movies and the material conditions that produce them. Like other worker communities, Hollywood is a social, not geographic entity, but unlike them, the public aura of their symbolic product shadows the real processes of capital accumulation: "the public never sees [J.P.] Morgan making money or [Henry] Ford making cars; but it does see [actor] Robert Taylor making faces" (ROSTEN, 1941, p. 18). This equivalence - between money, cars, and faces - is the basis for the alienation, in which thousands of workers are anonymous, "in the shadow" of a product with more value and power in the global economy than themselves (Ibid., p. 32). Hollywood merely indexed the national split between estranged labor and its objectified forms.

While certainly not radical in his deposition, Rosten was centrally concerned with the dialectic between workers' material conditions and their subjectivities. World War II, the closure of
European film markets, and the enforcement of anti-trust laws laid bare a political economy that accelerated capital accumulation: "The manufacture of movies substituted the problem of selling a commodity for the problem of 'having a wonderful time.' Hollywood was forced - more or less - to shift its attention from the Arabian Nights to Dun and Broadstreet." (Ibid., p. 28). Driven by profit motives, workers now sought individualist goals that emphasized competition over solidarity and strategic alliances over organic community. The objectification of their labor extended to self-objectification, in which elites consciously realized the need to promote their own celebrity through extravagant spending and highly public conjugal relations. Elites "cease to be individuals and become business institutions," writes Rosten, who interestingly observes them as the most alienated class (Ibid., p. 123). Paid far below business elites and less powerful than political elites, Hollywood elites seemed to have an "unconscious need for anxiety," that kept them swinging between elation and despair (Ibid., p. 39). Unable to assess their own value except through income and status comparisons, elites worked long hours but were perennially dissatisfied and discontent.

This insight that alienation was tied to the production process over the social class of the worker continued to be a dominant theme in Hortense Powdermaker's ethnography of Hollywood in the late-1940s. Like Rosten, 
Powdermaker found workers motivated first by profits, especially at the top of production hierarchies, where "the game becomes the ends and is played compulsively" (POWDERMAKER, 1950, p. 99). In addition, though, she spent far more time with workers at the bottom of these hierarchies, whose externalized labor rendered them as property that she compares to feudal serfs, African American slaves, prostitutes, and indentured servants (Ibid., p. 85, 149, 215). Although Marx characterizes alienation as a state of being under modern capitalism, Powdermaker's metaphors and their accompanying biographical stories of Hollywood actors, writers, and directors seem to show that profit is not the only value in a capitalist political economy. Rather, producers and executives often rejected a profitable employee in return for an imaginary ownership over the product. In this case, the studios hid net profits of films to exert greater control over their contracted producers, allowing executives to claim the product was in fact their creation.

The key to ownership in Powdermaker's text is the lack of freedom that workers trade for success in the industry. Freedom is not a break from alienation, in particular the estrangement that results from the division of labor, but seems to imply a role for workers to more openly collaborate in the labor process. When time rationalization, bureaucratic management, and commercial technologies displace the natural technologies of the self, "brains and talent" are neglected in favor of other resources (Ibid., p. 288). Powdermaker claims that producers deceive themselves into thinking of themselves as autonomous competitors rather than individuals tied to together by their potential for creative expression and hard work. Her assertion that freedom was not just desirable for many workers, but completely possible despite alienation, seems to give insight into why some workers accepted exploitative conditions in exchange for a self-realization through "a human form of collaboration" (Ibid., p. 303). This obvious contradiction, alienation but selfrealization through collaboration, adds a layer to the social theories of the day, showing that capitalism would be even more effective if it allowed workers to collaborate to realize each individual's organic talents.

Powdermaker and Rosten contribute empirical evidence to social theorizing of the era, most notably the piercing critique found in Max Horkheimer and Theodor Adorno's Dialectic of Enlightenment (HORKHEIMER; ADORNO, 1976). For them, alienation connected production and consumption, succeeding in "sacrificing whatever involved a distinction between the logic of the work and that of the social system" (Ibid., p. 121). Workers participate in an increasingly efficient industrial system of mass production and consumption, making them eventually "redundant as producers" of standardized objects and the liberal ideology of individual merit, competition, 
and desire (Ibid., p. 150). Elites control these processes of material and social standardization, while also reaffirming their unflinching allegiance to the system. On these points alone, Rosten's and Powdermaker's studies extend Horkheimer and Adorno's perceptions of alienation. First, they showed how different types of producers in Hollywood experienced alienation differently. Indeed, Rosten's elites were in many ways the most alienated. Second, these authors envisioned collective modes of creative ownership over production that would allow more control over the process while embedding them deeper into a system still driven by alienated labor and profit motives. In this respect, Powdermaker - the anthropologist, not the social theorist - is almost prescient in foregrounding the current era of team-based production and flexible work conditions that simultaneous liberate and harness creativity to generate profit. She predicts: "to liberate the unused resources of talent in Hollywood entails changes in the way of thinking, in the system of production which reflects the way of thinking and, finally, in the allocation of power" (POWDERMAKER, 1950, p. 303).

Compare these grounded theories of the dialectics of subjective formations and material exploitations with the relative lack of class critique today. In the new lexicon of production studies, producers frequently "negotiate" their way through "complex" social networks that all have more or less the same status and power. Producers are still anxious in studies that chart processes from the making of a documentary to the selling of a television series, but workers are also more likely to have independent agency and feel vindicated by a successful final product. In part, the political economy of the industry has changed. Film and television industries simultaneously promote teamwork and flexibility while espousing piecework and outsourcing. Creative production has been industrialized in accordance with Horkheimer and Adorno, but the production processes resemble more a bygone era of bohemian artists than the individuated factory floor. In their discussion of these material shifts, Luc Boltanski and Eve Chiapello propose that a new spirit of capitalism has stifled intellectual social critique by co-opting the language of $1960 \mathrm{~s}$ liberation into managerial-speak.

Success in this new spirit - autonomy, spontaneity, rhizomorphousness capacity, multitasking (in contrast to the narrow specialization in the old division of labour), conviviality, openness to others and novelty, availability, creativity, visionary institution, sensitivity to differences, listening to lived experience and receptiveness to a whole range of experiences, being attracted to informality and the search for interpersonal contacts - these are taken directly from the repertoire of May 1968. ${ }^{1}$ But these themes, which in the texts of the May movement were combined with a radical critique of capitalism... are often to be found in 
the neo-management literature autonomized, as it were - represented as objectives that are valid in their own right, and placed in the service of forces whose destruction they were intended to hasten. The critique of the division of labour, of hierarchy and supervision - that is to say, the way industrial capitalism alienates freedom - is thus detached from the critique of market alienation, of oppression by impersonal market forces (BOLTANSKI; CHIAPELLO, 2005, p. 97).

In one way, we might speculate that the new economy for film and television co-opted the values of artists in Powdermaker's era and turned them profitable, thus silencing critique from many who framed alienation in terms of factory work and assembly line production.

In another way, though, the problem of social theory building might also be a methodological issue. Rosten and Powdermaker, as developed more fully in other places (SULLIVAN, 2009; MAYER, 2008), had a special access to Hollywood's production personnel. Rosten worked in the industry; Powdermaker entered it on her own. In contrast, much of our work today comprises interviews on the phone or electronic correspondences, methods that open considerable distance between what subjects say about themselves and what they do. Observational methods are similarly limited. Executives give access to researchers to emphasize commercial successes and obscure failures. Corporate events are staged in spaces and at times when networks, advertisers, and trade industries celebrate themselves to gain market advantage and position themselves against competitors.

Given these difficulties, the job of building social theories grounded in the local experiences of practitioners seems as much a question of finding case studies that illustrate the times and places where the unexpected occurs and the rhetoric of achievement is called into question. Such was the case of a 2007 casting call in which I was a participant observer.

\section{The casting call as a case study in alienation}

I wanted to go to a casting call to witness what I had been interviewing workers about for over two years at this point. I was interested in reality casters, that is, the workers who cast the people that we eventually see under the broad umbrella of reality television programs. Reality casters are a prime example of invisible labor; their work is objectified in the cast member whose value is measured in ratings and advertising rates that can never be passed back to the caster. Production companies rarely even acknowledge the work of the caster in the form of program ending credits, which themselves have become illegible video streams alongside previews for other programs. Despite these mechanisms of alienation, casters in phone interviews were largely sanguine about their efforts, its value to the television industry, and their experience of the daily routines. When the opportunity arose for me to attend a live casting call as a participant-observer, I jumped 
to attend. I wanted to see how well the reality of the work matched with interviewees' selfappraisals of their work.

Like many casting calls, this one had to be organized quickly and somewhat at the last minute. The program succeeded in its extension through the television season, from the original nine episodes to thirteen. The producers were elated, but suddenly they would need four more episodes in an abbreviated time frame, from the initial three months of production to now a single month. Christmas holidays were looming and there would be few opportunities to get cast members if the production team did not act quickly. "Andrew," a casting associate for the program, felt the pressure": "This is the time I get nervous," he told me. "There's always the risk that no one shows and the affiliate puts all this work into the event for nothing".

The fear that labor would be wasted is a very real risk in assessing the value of a casting call. Television network affiliates frequently help production companies organize casting calls in the hopes that a local person will be selected for the cast. The local person is a commodity that boosts affiliates' advertising rates for the program and can be tied to promotional events for the station. One classic example: Fox News affiliates frequently chronicle the progress of local contestants on their network's program American Idol. In turn, the network program often broadcasts these local outpourings of emotion for the local contestant at planned fan parties and welcome home gatherings sponsored by the affiliates. The longer the local stays in the program, the higher the exchange value for the affiliate. The search for a local cast member is therefore a type of lottery for numerous workers in that gauged their own success on the chance that their work could be objectified in the form of a contestant, character, or participant who not only appeared on the screen, but might reappear. This economy was the basis for workers' anxieties throughout the production team, broadcast networks, and their affiliates, as well as the foundation for guaranteed alienation from the product of their labors.

The anxiety was palpable around this particular call, which targeted families with small children. I arrived well ahead of the 3 p.m. start time to a kids' daycare facility, one in which upper-middle class families bought memberships so that their children had a designated play space in the large urban environment in which they grew up. Andrew's team and the local television affiliate had convinced the owner of the facility that by hosting the call, they would cross-promote

2 All names have been changed in accordance with the guidelines for human subjects' anonymity as required by the Tulane Office of Human Research Protection. In addition, all names of identifying features of the program associated with this casting call have been obscured to the best of my abilities. 
the daycare company. The owner "Jeff" said he expected no less than thirty families as he cleared two spaces in the kitchen area: one table for interviews and another for those queued to interview. On the first table, Andrew had neatly arranged pens and applications. He searched for chairs and made phone calls to the television affiliate contacts. On the second table, "Natalie," Jeff's employee, had laid out a spread of cookies, crackers, juice boxes, and other snacks for at least fifty attendees. She also inflated helium balloons and decorated the entire warehouse space with streamers. Jeff placed a life-size standee from the program at the front door with signs he had commissioned from the local copy shop. Nervously, he chewed out the mail service representative that had guaranteed that twenty copies of the book authored by the program's host would arrive in time. Jeff had invested several hundred dollars in accessorizing the call. He said he just wanted "to break even" to justify his investment, but he spent the afternoon talking about how much the event cost and how he hoped to generate new customers and turn a profit to justify the work. "I think we'll have at least thirty families today," Jeff said again, repeating his sanguine prediction, but perhaps less sure of himself this time.

Andrew was less optimistic on this point, guessing that perhaps five families would attend the call. He knew from experience that families were a difficult demographic if only because it required the target audience to coordinate their schedules and travel to a remote location. Further, it was the first cold snap of the winter season in the city, making an outdoor excursion even less likely. We sat down at the interview table and waited. A news cameraman for the affiliate station who arrived to record the expected crowd also waited. "If there's a fire, I'm out of here", he stated, but three hours later, we were all still there. Not a single applicant came to the casting call.

Jeff was distraught, having spent weeks on preparation and invested income on the event no one came to. The cameraman was bored, flipping through children's books in the play area. Even Andrew, who was upbeat in his interactions with me, was now disappointed, having incorrectly predicted that his efforts would bear results. Although he did not expect a crowd, he hoped that applicants would at least call in to the daycare to inquire about the call. The only product produced after four people worked for five hours that day was a videotape of Jeff's three children, Andrew, and me watching an episode of the program itself on television. The cameraman delivered the tape to the affiliate newsroom for the evening's late night broadcast.

The invisible and, ultimately, unproductive labors of workers for the production company, the television affiliate, and the daycare, as well as the owner, belie the obvious aspects of alienated labor involved in many, if not most, casting calls. Quite simply, a lot of time and effort goes to waste in finding "real people" that could just as 
easily be found next door, at the supermarket, or in the shopping mall. The exchange value of the call relates more to whether local media industries can capitalize on an on-screen participant as a brand, something that may have no relation to the efforts of those involved with casting calls. Instead, the process of the casting call and its reception by the people I observed gives some insights into how alienation makes working subjects. This particular casting call demanded coordination and collaboration between various types of workers, which, in the beginning, seemed full of potential and enthusiasm, but, ultimately, resulted in boredom and some isolation as workers faced the individual consequences of the call's failure. The clear separation of the production process from the product created anxiety, and then disappointment, when the process failed to produce the applicants. At another level, though, the business owner Jeff most embodied these emotions. He clearly felt the most at stake in attracting publicity, so much so, he commodified his own kin in a staged news clip.

In contrast, Andrew, who felt pressure to deliver participants for the program, could also look to other mechanisms for gathering applicants, such as phone calls and the news clip itself, which would promote calls to the production base in Hollywood. "People will see the episode tonight and then the news story that we want local families", he said. "After the program airs, we can get 100-200 calls. So this [event] is all part of outreach." Whereas alienation made for nervous workers throughout the operation, calling attention to their lack of control over the object, the investments in each person's role still led to individuated experiences of the event, creating tensions.

Another factor that might help us to understand these tensions were the trajectories of these workers, in particular Jeff and Andrew. The former had left a career in hotel management to become a business owner. The latter was an artist by training, working as a casting director to support his primary career goal. Both talked about these alternative careers during the long wait for applicants. Andrew stressed, "I really do this to pay the bills." In contrast, Jeff said he "put everything" into the business: "My years in hospitality are the basis for what I'm trying to do here." While this might be a facile comparison, it is also possible to see how media industries manage alienation by spreading the risk of failure through organizational networks. Production studios benefit when they hire workers who can defer their insecurities either to other collaborators or to other pursuits outside of the industry. Of course, these insecurities return, as in that nagging feeling that Andrew had at the beginning of the event. Yet, the object lesson of the casting call might be how failure in the production process has the power to reveal workers' alienation to themselves, but the industry's structure also gives them the alibis for explaining it away. Again, workers 
experience this differently. The younger casting director still hoped his art would be the path from alienation, explaining away the failure of day as a step towards unification with an artist community; while the older business owner narrated the success of this event as an indicator whether his skills from the hospitality industry can help him achieve his own financial independence.

\section{Productive theorizing from production failures?}

Alienation seems to be a continuing feature of modern production, whether in the refurbished industrial space of a daycare or in the postindustrial practices of the reality caster waiting for the next contract. Production studies offer the opportunity not just to confirm the ongoing presence of this social phenomenon locally, but theorize, from the ground, how it "works": making producers into productive subjects. Television programs, the result of hundreds of micro-processes from script-writing to distribution, rely on thousands of collaborative efforts, but without some form of fieldwork it is hard to know how these collaborations manifest to make workers accept the fact that the arrangements result in uncompensated labors. While one case study cannot illuminate the range of possible experiences of alienation, it can become one of the building blocks for a theory that shows the variations among workers, based on their role in a collaborative project, their career trajectory, and their future opportunities. This is an opportunity not to repackage the insights of past production studies, but to replace it in light of a new economy of film and television production.

The casting call seemed to present alienation not just in flashes of recognition that the work was devalued, usurped, or erased, but also in the deferral to the next project. For this reason, local production studies might also focus more on failures in the production process, what did not work or go well according to industrial standards. Not only are the failures simply necessary for defining success, they can be productive in themselves as a critique of capitalism. Failures, as Judith Halberstam has noted, open the potential for re-imagining resistance as a queer space, not quite submissive but not quite revolutionary either (HALBERSTAM, 2006). In this sense, the casting call that failed to attract attention was precisely the moment that revealed the real work of casters: to justify the failure, create an alternative narrative of the event, and move on. Still, a resistive spark remained. Despite his enthusiasm for the job and the optimism for the future, Andrew complained that at times his job seemed "thankless" to him, "I've cast shows where I don't even get invited to the final wrap party." If alienation operates to disconnect workers from their labors, we see in Andrew's comment a recognition and a rejection of any starry-eyed admiration for the industry, perhaps sowing a seed for future resistance. 


\section{References}

BOLTANSKI, Luc; CHIAPELLO, Eve. The new spirit of capitalism. Translation: Gregory Elliott. London: Verso, 2005.

HALBERSTAM, Judith. Notes on failure (lecture).

Urbana: University of Illinois, 2006.

HORKHEIMER, Max; ADORNO, Theodor W. The dialectic of enlightenment (1947) London:

Continuum, 1976.

MARX, Karl. Economic and philosophical manuscripts (1844). In: MC LELLAN, David (ed.), Karl Marx: selected writings. 2. ed. Oxford: 0xford University Press, 2000. p. 89-91.

MAYER, Vicki. Studying up and f**cking up: ethnographic interviewing in production studies. Cinema Journal, Austin, v. 47, n. 2, p. 141-148, 2008. POWDERMAKER, Hortense. Hollywood the dream factory. New York: Little, Brown and Company, 1950. ROSTEN, Leo Calvin. Hollywood: the movie colony, the movie makers. New York: Harcourt, Brace and Company, 1941.

SULLIVAN, John. Leo C. Rosten's Hollywood: power, status and the primacy of economic and social networks in cultural production. In: MAYER, Vicki; BANKS, Miranda; CALDWELL, John T. (eds.) Production studies: cultural studies of media industries. New York: Routledge, 2009. p. 39-53. 
Reincorporar lo "social": estudios de la teoría social y la cultura de producción

\section{Resumen}

El presente artículo sostiene que los estudios sobre la producción de los medios de comunicación deberían basarse en los estudios de casos para poder evaluar y reformular las clásicas teorías de producción en vista del nuevo espíritu de capitalismo. Es decir, se presentará un trabajo de campo sobre directores de reparto en la industria de la televisión-realidad, quienes no han podido lograr sus metas de producción. Así, se propone que los fracasos en el trabajo pueden iluminar cómo el concepto social de la enajenación se realiza por medio de los procesos de la producción televisiva. Palabras clave: Enajenación. Fracaso. Estudios de la producción. Televisión-realidad. Teoría social.

\section{Palabras clave}

Enajenación. Fracaso. Estudios de la producción. Televisión-realidad. Teoría social.

\section{0 retomo ao "social": estudos de teoria social e cultura da produção}

\section{Resumo}

Neste artigo, argumenta-se que os estudos de produção devem utilizar o estudo de caso fundamentado para examinar e reformular as teorias clássicas da produção à luz da fase atual do capitalismo tardio. Para comprovar o argumento, apresento uma pesquisa de campo com a equipe de escalação dos participantes de um reality show que falha na função de produção do "elenco" para 0 programa. Neste caso, o erro da equipe deve ilustrar como a alienação é vivida no processo de produção televisiva.

\section{Palavras-chave}

Alienação. Fracasso. Estudos de produção. Reality show. Teoria social. 


\section{Expediente}

A revista E-Compós é a publicação científica em formato eletrônico da Associação Nacional dos Programas de Pós-Graduação em Comunicação (Compós). Lançada em 2004, tem como principal finalidade difundir a produção acadêmica de pesquisadores da área de Comunicação, inseridos em instituições do Brasil e do exterior.
E-COMPÓS I www.e-compos.org.br I E-ISSN 1808-2599

Revista da Associação Nacional dos Programas de Pós-Graduação em Comunicação. Brasília, v.12, n.3, set./dez. 2009.

A identificação das edições, a partir de 2008 passa a ser volume anual com três números.

\section{CONSELHO EDITORIAL}

Afonso Albuquerque

Universidade Federal Fluminense, Brasil

Alberto Carlos Augusto Klein

Universidade Estadual de Londrina, Brasi

Alex Fernando Teixeira Primo

Universidade Federal do Rio Grande do Sul, Brasil

Alfredo Vizeu

Universidade Federal de Pernambuco, Brasi

Ana Carolina Damboriarena Escosteguy

Pontifícia Universidade Católica do Rio Grande do Sul, Brasil

Ana Silvia Lopes Davi Médola

Universidade Estadual Paulista, Brasil

André Luiz Martins Lemos

Universidade Federal da Bahia, Brasil

Ângela Freire Prysthon

Universidade Federal de Pernambuco, Brasil

Antônio Fausto Neto

Universidade do Vale do Rio dos Sinos, Brasil

Antonio Carlos Hohlfeldt

Pontifícia Universidade Católica do Rio Grande do Sul, Brasil

Arlindo Ribeiro Machado

Universidade de São Paulo, Brasil

César Geraldo Guimarães

Universidade Federal de Minas Gerais, Brasi

Cristiane Freitas Gutfreind

Pontifícia Universidade Católica do Rio Grande do Sul, Brasil

Denilson Lopes

Universidade Federal do Rio de Janeiro, Brasil

Eduardo Peñuela Cañizal

Universidade Paulista, Brasil

Erick Felinto de Oliveira

Universidade do Estado do Rio de Janeiro, Brasil

Francisco Menezes Martins

Universidade Tuiuti do Paraná, Brasil

Gelson Santana

Universidade Anhembi/Morumbi, Brasil

Goiamérico Felício

Universidade Federal de Goiás, Brasil

Hector Ospina

Universidad de Manizales, Colômbia

Herom Vargas

Universidade Municipal de São Caetano do Sul, Brasil

leda Tucherman

Universidade Federal do Rio de Janeiro, Brasil

Itania Maria Mota Gomes

Universidade Federal da Bahia, Brasil

Janice Caiafa

Universidade Federal do Rio de Janeiro, Brasil

Jeder Silveira Janotti Junior

Universidade Federal da Bahia, Brasil

\section{João Freire Filho}

Universidade Federal do Rio de Janeiro, Brasil

John DH Downing

University of Texas at Austin, Estados Unidos

José Luiz Aidar Prado

Pontifícia Universidade Católica de São Paulo, Brasil

José Luiz Warren Jardim Gomes Braga

Universidade do Vale do Rio dos Sinos, Brasi

Juremir Machado da Silva

Pontifícia Universidade Católica do Rio Grande do Sul, Brasil

Lorraine Leu

University of Bristol, Grã-Bretanha

Luiz Claudio Martino

Universidade de Brasília, Brasil

Maria Immacolata Vassallo de Lopes

Universidade de São Paulo, Brasil

Maria Lucia Santaella

Pontifícia Universidade Católica de São Paulo, Brasil

Mauro Pereira Porto

Tulane University, Estados Unidos

Muniz Sodre de Araujo Cabral

Universidade Federal do Rio de Janeiro, Brasil

Nilda Aparecida Jacks

Universidade Federal do Rio Grande do Sul, Brasil

Paulo Roberto Gibaldi Vaz

Universidade Federal do Rio de Janeiro, Brasil

Renato Cordeiro Gomes

Pontifícia Universidade Católica do Rio de Janeiro, Brasil

Ronaldo George Helal

Universidade do Estado do Rio de Janeiro, Brasil

Rosana de Lima Soares

Universidade de São Paulo, Brasil

Rossana Reguillo

Instituto Tecnológico y de Estudios Superiores do Occidente, México

Rousiley Celi Moreira Maia

Universidade Federal de Minas Gerais, Brasil

Samuel Paiva

Universidade Federal de São Carlos, Brasil

Sebastião Albano

Universidade Federal do Rio Grande do Norte, Brasil

Sebastião Carlos de Morais Squirra

Universidade Metodista de São Paulo, Brasil

Simone Maria Andrade Pereira de Sá

Universidade Federal Fluminense, Brasi

Suzete Venturelli

Universidade de Brasília, Brasil

Valério Cruz Brittos

Universidade do Vale do Rio dos Sinos, Brasil

Veneza Mayora Ronsini

Universidade Federal de Santa Maria, Brasil

Vera Regina Veiga França

Universidade Federal de Minas Gerais, Brasi

\section{COMISSÃO EDITORIAL}

Felipe da Costa Trotta I Universidade Federal de Pernambuco, Brasil Rose Melo Rocha I Escola Superior de Propaganda e Marketing, Brasil

\section{CONSULTORES AD HOC}

Arthur Autran Franco de Sá Neto I Universidade Federal de São Carlos

Carlos Eduardo Franciscato I Universidade Federal de Sergipe

Elisa Reinhardt Piedras I Universidade Federal do Rio Grande do Su

Elizabeth Bastos Duarte I Universidade Federal de Santa Maria

Marcia Benetti Machado I Universidade Federal do Rio Grande do Sul

Sandra Maria Lúcia Pereira Gonçalves I Universidade Federal do Rio Grande do Sul

Suzana Kilpp I Universidade do Vale do Rio dos Sinos

Tattiana Gonçalves Teixeira I Universidade Federal de Santa Catarina

Vander Casaqui I Escola Superior de Propaganda e Marketing

Vicente Gosciola I Universidade Anhembi Morumbi

Walter Teixeira Lima Junior I Fundação Cásper Líbero

REVISÃO DE TEXTO E TRADUÇÃO I Everton Cardoso

EDITORAÇ̃̃ ELETRÔNICA I Raquel Castedo
COMPóS I www.compos.org.br

Associação Nacional dos Programas de Pós-Graduação em Comunicação

Presidente

Itania Maria Mota Gomes

Universidade Federal da Bahia, Brasil

itania@ufba.br

Vice-presidente

Julio Pinto

Pontifícia Universidade Católica de Minas Gerais, Brasil

juliopinto@pucminas.br

Secretária-Geral

Ana Carolina Escosteguy

Pontifícia Universidade Católica do Rio Grande do Sul, Brasil

carolad@pucrs.br 